\title{
Understanding the Transition and Implications of Merger in a Merged Multi-Campus University in South Africa: Human Resource Perspective
}

\author{
Prof Emmanuel O. Adu Ph.D. \\ Faculty of Education, University of Fort Hare, South Africa \\ eadu@ufh.ac.za \\ Lunga Xolisa Mantashe \\ Faculty of Education, University of Fort Hare, South Africa \\ lungas133@webmail.co.za
}

Doi:10.5901/mjss.2014.v5n23p1516

\begin{abstract}
Change is a way of life for organisations, managers and workers in general. It is a real phenomenon and a risky affair that demands systems change. It demands attention of highest note because it has an effect or impact on operations and structures of the organisation operations. No amount of pretention, prevention, resistance or even denial can change constancy of change. This paper examines the understanding of the transition and implications of merger in a merged multi-campus university in South Africa the human resource perspective. The paper succinctly described merger policy and the complexities brought by it; restructuring and re-organisation; how to manage transition and sustain momentum. The paper does not leave behind the managerial leadership of change and transition with specific skills in transitional periods. The paper however concluded that an organisation is constantly adapting and can never be static in a changing environment. Consequently psychological contracts can be broken during such times of restructuring and obviously this affects the workers in a special way and as such needs proper handling.
\end{abstract}

Keywords: Merger, South Africa, Multi-Campus, Restructuring, Transition, Human resource

\section{Introduction}

Organisations are constantly in a state of change, though to varying degrees, because change is itself a dynamic and ongoing process that needs to be managed. This is because nothing is static; everything is in the process of evolving and becoming every time. Chen (2006) says that though organisations are not intended to change, changes affect all types of organisations. Therefore, organisations are not spared the pains and benefits of change. Paton and McCalman (2001) says that change cannot be separated from an organisation and will therefore not disappear or dissipate. Because organisations do not have a choice, especially given the fact that they are confronted with pressures, Burnes (2004) suggests that there is a possible downfall when organisations do not change. The author implies that pretending or delayering changing may lead to the downfall of organisations. The author says that change is imposed upon organisations by challenges. These can be internal or external. That is beside the point, especially for the purposes of this study. The point is that when change occurs, because it in a real life situation, in real organisations, it affects humans and inherently demands reconfiguration of structure.

Leanna and Barry (2000) call change a way of life for organisations, managers and workers in general. It is a real phenomenon (Kritsonis, 2005:1) and a risky affair that demands systems change (Seijts and O' Farrell, 2003). It demands attention of highest note because it has an effect or impact on operations and structures of the organisation operations (Govender, Moodley, and Parumasur, 2005). No amount of pretention, prevention, resistance or even denial can change constancy of change. It is a necessary menace because its consistent spectre, terrorising and devastating as it may be in many cases, expresses, in its inherent nature, form and content, a prospect for dynamic, creative and proactive thinking about the future of individuals, groups and general organisations.

Ajay (2002) contends that change is an illogical and emotional process in the life of humans. P'eli et al. (2000) warns that change is disruptive in that it erodes the organisation's accountability and reliability, possibly leading to frustration and confusion in the organisation itself. The destabilised process follows and forces re-shaping and realignment of the organisation (Dahl, 2010) and further complicates the problem in that employee turnover, because of 
dissatisfaction (Baron, Hannan and Burton, 2001), becomes a new reality which organisations have to deal with. In essence it can be said that change is a necessary permanent evil that institutions must grapple with. Instead of preventing and delaying it; leaders and managers must establish platforms and forums for excavating, exposing and exploring alternate ways to change current affairs. No organisation or institution should therefore be content with the present for they may inherently hold a conservative philosophy: those things are best left as they are.

Important in the understanding of the concept of change, specifically in the context of the research under study, is to know that it is a process. The study looks at the implications of structural change in terms of the transition from the unitary to a more decentralised model of management. Kritsonis (2005) advised that change can be observed and analysed through various steps or phases. According to Lewin (1951) these steps are unfreezing, movement and refreezing. Suffice to say that these steps already indicate a process of change which at most organisations should try to follow when undergoing change.

Higher education has undergone serious changes in the years of the new millennium. These changes include, but not limited to, introduction of mergers of multi campuses, decisions about how new identities, cultures, policies and the entire conception of restructuring of models of management. Below the researcher addresses briefly the background, beginning with mergers and finally addressing the movement from a merged problematic stage to an even more complex stage of actually dealing with complexities relating to management models.

\section{Merger Policy}

The researcher situates the suggested problem, in this study, of the unworkable unitary management model of a particular university (Ncayiyana, 2011; Higher Education Quality Committee, 2011) accurately within a historical context of the merger policy of HEls in South Africa. The reason for doing so is that the suggested problem reflects the transformation from a failed post-merger model of management to a new Divisional Management Model (DMM). Consequently, change, the product of merger and the current model of management, has implications on HR, the people. These implications are direct or indirect, and positive or negative.

In March 2001, the South African Minister of Education released a National Plan for Higher Education according to which the number of public higher education institutions would be reduced from thirty-six (36) to twenty-three (23), with eleven (11) being traditional universities and six (6) being universities of technology (Ministry of education, 2001). In 2002, the African National Congress led government induced and enacted a policy of mergers of HEls in South Africa (BuaNews, 2003). The policy was coerced despite serious contestations against it (Jansen, 2003), among which, for example, was the political motivation for changing the landscape in South African HEls (Schultz, 2009). In addition to being political in South African context, Harman and Meek (2002) suggested that other reasons to induce the merger policy were financial.

Generally the idea inherent in the policy to merge HEls was that of:

- Creating a unified national system of education (Wyngaard and Kapp 2004);

- Increasing access to education, particularly where previously disadvantaged would be given an equal chance to access to education (Harman and Meek , 2002); and

- Responding to the changing society in terms of technology, global and national demands and economic needs (Mapasela and Hay 2005).

Merger policy in South Africa, however, was also prompted by a global trend of mergers. For example, many countries have undergone the process of merger: Canada, Great Britain, Germany, the Netherlands, Norway, Sweden, Hungary, Vietnam, New Zealand and Australia to name a few (Harman and Meek, 2002). Harman and Harman, (2003) also revealed that restructuring of Higher Education sought to solve problems associated with fragmentation and with small size colleges. However these mergers have caused serious challenges and they are, some of them, addressed briefly below.

\section{Complexities Brought by Merger Policy}

Skodvin (1999) says that mergers do not affect the governing systems of the institutions; the very soul of the partners involved in the process is also affected. The institutional changes include the abandonment of existing forms of governance, change in institutional norms, objectives and academic programmes, as well as the modification of organisational procedures (Skodvin, 1999:68). thus, the coming together of all separate colleges, technologies and universities and the formation multi-campus institutions (Harman and Harman, 2003) implied that distinct institutions would be importing their institutional challenges, structural weaknesses in to the newly merged multi-campus universities 
with the same underlying structures. These complexities further the life of the new organisations/universities in that the latter had to grapple with realities relating to finances, institutional culture, values and Human Resource (HR). Schultz (2009) points out that mergers also had unintended consequences on employees' commitment and thus organisational performance was affected. The author suggested that there is a need to realign people management to support the business strategy to meet its organisational desires.

What the above paragraph expresses is a problem of the HR unit management in the context of change. The Human Resource of any institution of higher learning that has undergone a merger is more that significant. It determines whether a merger succeeds or fails. In fact, research has shown that from $55 \%-70 \%$ of mergers fail because HR issues are neglected (Schraeder and Self 2003). Sidumba (2011) adds that HR issues are part of the reasons some merged universities had to unbundle. It is also suggested that at times relationships between employees and organisations changed, leading to decrease in employee commitment (Van Strateen Theron and Dodd, 2011). Lalla (2009), for example, found that management relationships, job security, job position and promotion, communication, performance standards and collegial relationships were all negatively impacted on by the merger at a particular institution.

This is all evidence suggesting that an organisation, once the HR aspect in neglected, suffers terribly in terms of meeting its organisational goals. Van Strateen Theoron and Dodd (2011) appreciate this and further expose the fact that psychological contracts between the institutions and employees have become brittle and prone to breach, compelling management to pay closer attention to the employment relationship in order to maintain commitment and loyalty. These complexities during change have not only been manifest, universities also had to rethink systems, structures and models with which to manage and govern their respective multi merged universities. The institution/university under study experienced such processes of structural management changes and there is a brief explanation below to that effect

\section{From Merger Policy to Management Models: Restructuring and Reorganisation}

Prompted by the institutional audit done by HEQC and the report of the assessor in 2011 , one university had to change the unitary model because it was not working well (WSU, 2014); it needed to design a suitable organisational structure for a widely dispersed merged multi-campus university (HEQC, 2011 and Ncayiyana, 2011). The restructuring entailed thinking about all constituent elements (ICT, finance, governance and management in terms of authority distribution and $\mathrm{HR}$ ) and how they would fit the new model of the future. This meant that the earlier structure was incapable of resolving complexities relating to allocation of finances, academic architecture and HR. Thus a new structure that is capable of creating a truly integrated, efficient and effective model had to be created.

According to Viljoen and Rothman (2002), it was expected that the transformation of Higher Education in South Africa would include the revolutionary change of previous management practices; qualitative change in the experience of organisational members; and multi-dimensional change, which refers to the changes of all structures, processes and procedures and their attendant change in values, norms, attitudes, perceptions and behaviour. It can be added that merger policy undoubtedly, especially because of complications it brought to the organisational structures of merged institutions, inherently demanded change in management models. In fact the implications of the merger in a particular university were such that they sparked a need for further change in the management model because the unitary management model was unworkable (HEQC, 2011), left the institution at war with itself (Ncayiyana, 2011) and potentially domed the University Permanent Paralysis and failure. However where the current model under study has been implemented, it has not been without challenges of its own. For example CHET (2008) pointed out that in NWU staff and students did not fully understand when it is that an institutional office can intervene. Moreover they complained that the model simply benefited their superior previous main campus.

They lamented that with the emergence of the model, competent staff has been absorbed by the institutional offices, leaving weaker campuses struggling with regards to human capital. Finally they complained that people in the institutional office predominantly came from the bigger campus, which meant that the model favoured and benefits the bigger campus only. These challenges are significant because they reflect the reactions of workers and thus give indications of their perceptions, attitudes and feelings about progress of the model. The uniqueness of the DMM management model in the South African context (Stumpf, 2008), particularly in the specific contexts of a semi-rural, semisuburban and semi-township campuses within which this Model is been implemented (Mantashe, 2013) makes it is apt for this research to understand this change, the process of transition and explore its implications on the Human Resource aspect in particular. 


\subsection{Manage transition}

Following all preparation work comes the difficult part of implementing, managing and consolidating the actual change process (Mabey, 2007). The transition state is typified by a number of problems. "There is invariably, confusion about roles, responsibilities and decision making channels as "steady-state" management is disrupted.

Some people cope with ambiguity better than others, although the setting up of communication feedback mechanisms, periodic cross-functional meetings and temporary task team help" (Mabey, 2007:46).

\subsection{Sustain momentum}

Mabey (2007) states that at some point it is necessary to access the impact of the various change initiatives that have been set in motion. Because the feedback of positive outcomes is an important aspect in giving momentum to the change programme, early success stories help to foster expectancy among those yet to participate or to be affected by the change effort (Mabey, 2007). "Where various initiatives are not working, some of the earlier steps in the six step model may need to be revisited. Whatever the situation, the changes 'sponsor' need to be kept informed (Mabey, 2007:53.)

What comes after the explication of the change management models is a discussion on managerial leadership and an exposition of why the two (management and leadership), even though both are applicable to planned change models, are distinct and have unique contribution and application to the same processes of transition. Particularly the purpose of delineating these concepts is not to argue that they stand aloof from each other, neither is it purely an intellectual pursuit for a perfectionist argument; rather it is to demonstrate, as it will be clear in the later discussion [which is about leadership styles: transformational and transactional leadership] that it is erroneous and fatal to simply assume that managers are leaders without ascribing what it means for a manager to be a leader and the latter to be the former during the processes of transitioning people and organisations.

\section{Managerial Leadership of Change}

Categorically speaking, there is a fine distinction between leadership and management. It is not only academic; it is also practical. However the two are not mutually exclusive. On the contrary they are two distinctive by complimentary systems of action (Kotter, 1998). For example, while management is about coping with complexity, leadership is about coping with change. Management is concerned largely with managing change in such a way that there is stability in the institution or organisation and leadership is largely concerned with the idea of creating change (Zalenick, 1977). Leadership implies that somebody occupies an office and a position which gets to account for change in the organisation (Barker, 1997).

In this case the leader is tasked to work creatively and proactively in creating a suitable environment for effective successful change, while a manager must make possible compliance to processes and procedures put in place when undergoing change. Kotter (1990) delineates the functions of managers and leaders thus:

- Managers manage complexity by planning, budgeting, organising, staffing, controlling and producing predictability, order and stability

- Leaders on the other hand lead by setting a direction, aligning people, motivating and inspiring and producing useful dramatic change.

It is fair therefore to rely on Woodward and Dobson (2002) when they say that all managers are leaders because they both help others to achieve goals. One cannot be a manager of effective nature unless one possesses the necessary leadership for leading such change.

Barker (1997) coins a concept "managerial leadership" in order to put a leader in the context of an organisation in which the leader is held accountable for the management of change. This seems to immediately assume that a manager must necessarily have particular leadership qualities. It further implies that management skills are not enough.

According to these authors, managerial leadership is underpinned by the notion of a leader as "a giver of direction, a manipulator of will, who frames and solves specific managerial and social problems, resulting from a need for an imposed order and from the need to accomplish specific goals (Barker, 1997, p. 350). Seitjs and O'Farrell (2003) adds that leaderships includes directing the organisation, motivating people and stimulating their behaviours and attitudes to be consistent with the direction the organisation is taking, and coaching them on how to wrestle against complexities and barriers to change. The reason for coaching and guiding behaviours is that these are of primary significance in a transformation process (Eisenbach, Watson and Pillay, 1999). Behaviour of workers is important and merits attention from the leadership of change, otherwise without its transformation; it is hard to believe that successful change can occur. Govender, Moodley, and Parumasur (2005) confirms that in a work environment behaviour is linked to the functions that 
people perform and therefore new roles and responsibilities necessarily require adaptation on the part of the behaviour and attitudes of individuals.

This assertion by these authors must already be an advice to the leaders during change: managerial leadership should not ignore reactions in the process of transforming attitudes, behaviours, feelings and general narratives of the workers during transition. This is because the goals of the organisation are better realised when the leadership in the management of change is capable of nurturing positive attitudes to the workers that are affected by change (Govender, Moodley, and Parumasur, 2005).

\section{Effective Leadership during Change and Transition}

A number of authors such as Groenewald and Ashfield (2008), Hughes (2010) and Stander and Rothman (2010) suggest that that leadership is imperative in the successful implementation of change. The reason is that effective leaders envision the future, align people with a vision and influence them to realise it (Kotter, 1996).

No matter how good management may be during transition from the status quo to a changed scenario, it may not be adequate; leadership is necessary to motivate, influence and inspire employees and the rest of organisational members to accept, help implement and facilitate change. Change creates a need for leadership and leaders who are, or are perceived to be, initiators and drivers of change (Schuller, 1996, p.76). Such leaders, as contemplated by the author, foster change, create the future and move people where they are better off. Leadership within a complex organisation achieves this function through sub-three processes, namely establishing direction, aligning people and motivating and inspiring (Kruger, 2003).

The immediate question that cannot be escaped during transitional periods in organisations is: what leaders are needed in order to collectively make transition smooth? Before that we must comprehend the concept of leadership. Daft (1998) says that leadership is most widely presented and discussed topic in the literature of management and organisation. However it is not an easy concept to define and it is difficult to study and understand (Chen, 2003). Barrett (2008) adds that researchers seldom utterly agree on how best to define the concept of leadership. In order to bring some sort of understanding about leadership, Chen (2006) says that behaviour of leader enables us to see and feel the existence leadership. The author goes on to argue that leadership exists when man influences others for the attainment of organisational goals.

Many researchers and scholars have this to say about leadership: leadership is the ability to influence members to voluntarily pursue organizational goals and that leadership is the use of non-coercive and symbolic influence to direct and coordinate the activities of the members of an organized group toward the accomplishment of group objectives (Bateman and Snell, 2002, p. 380; Kinicki and Williams, 2003, p. 448). Another author says, in addition, that leadership refers to the men or women, who may not necessarily be Presidents or Chief Executive Officers, who influence others, command others' attention, persuade others to follow them or pursue defined goals: control situations, improve the performance of groups and organisations and get results (Barrett, 2008, p. 3).

Nadler and Nadler (1998) summarily argue, and put leaders in their proper context when they say that leaders are change champions. Sidra et al (2006) further says that leadership forms the essence of change management processes. This is so because at the top management of an organisation leaders exist to keep the process of change and maintain the operational reliability of the organisation (Nadler and Nadler, 1998). Their being champions of change is derived from the fact that they have power or authority to organise people or group/team in order to direct and lead them for the accomplishment of tasks or goals of organisations (Sidra, et al. 2006). This validates the fact that change hinges strategically on leadership. Go vender et al. (2005) confirm the validity of this statement when they say that change needs leadership support, without which it is likely to collapse.

We need to go a step further in our quest of establishing a thorough comprehension of leadership. The latter has two foundational components in itself: power and personality traits (Ruth, 1996). Power is an ability to influence, command and order others to do something they would not have otherwise done (Chen, 2006). The latter author says that such power is intangible and abstract; it can only be felt but cannot be seen or touched. Daft (1998) says that such power does not necessarily have to be used vertically; it can be exercised in a horizontal way. There are five sources of power, and the researcher believes leadership during change already has and can exercise complementary: coercive, expert, legitimate, referent and reward power (Daft and Marcic, 2004, p. 414-5).

Personality trait as defined by scientists and psychologists are any persisting characteristic of dimension of personality according to which individuals can be rated or measured (Coon, 1998, pp. 519-27 and Plotnik, 1996, p. 424). Chen (2006) confirms that many researchers organise personality traits under five categories: openness, conscientiousness, extroversion, agreeableness, and neuroticism. Sidra et al (2006) also add that there as personality 
traits that good leaders should have in the process of leading change these are: Self-confidence; ambition; drive and tenacity; Realism psychological openness, Appetite for learning, Creativity, and fairness. Moreover the authors argue that leaders should be able to work with teams in the organisation in the quest to achieve the aims and objectives of the organisation. One author summarily says that leaders should be architects, teachers and stewards (Senge, 1990).

These three qualities assist in clarifying mission, vision and values; identifying strategies, structure and policies, generating efficient learning processes, and facilitating subordinates to develop their mental model continuously and think systematically (Sidra et al, 2006:116). Overlaying power and personality traits are leadership competencies (Chen, 2006). These competencies are: cognitive, technical and affective competence Chen and Chang, 2001 and Rue and Byars, 2003:263-83).

\section{Specific Skills Leadership Skills in Transitional Times}

Leaders of change who are in the management of an organisation need capabilities because strong leadership that can effectively make change possible and ensures a smooth transition. Management and leadership styles need to be adjusted and responsive to the changing environment if hurdles to success must be minimised (Bossidy and Charan; Gilley, 2005). However one authors takes our attention to another reality during times of change when he argues that "organisations often do not have people who are sufficiently skilled to handle change" (Carnall, 1999:106). Thus the leadership during transition must be such that they possess dexterity in balancing organisational interests and people's interests during change. Below we discuss some specific skills leaders need to have for change to have better prospects for success.

\subsection{Political skills}

Every organisation is a social system in that it is primarily constituted by people (Nickols, 2010). People who work for an organisation have different interests, preferences and narratives about how the organisation is or should contribute to their personal growth and objectives.

Nickols (2010) suggests that an organisation is hotly and intensely political so that the change agent needs some acumen in order to manage politics. What makes organisations more political is the emergence of group thinking in the form of unions who speak and represent the interests of workers in that organisation. Such workers have bargaining power and therefore a political strategy is needed to circumvent lack of smooth transitioning. Benveniste (1989) cautions that even well thought-out plans about change can be derailed and fail if the politics of implementation are not considered. Considering these politics requires change agents to appreciate the existence of formal and informal groups. It requires an ability of the change masters to lobby, form interactive networks with all interest groups who may hold change at ransom (Benveniste, 1989).

\subsection{Analytical skills}

Insofar as analytic skills are concerned, Nickols (2010) asserts that a change managerial leader has to be dexterous in analysis. This analysis refers to the ability to gain insight of the processes of the organisation in relation to the people who must change, engaging in a lucid rational analysis of systems, processes, structures, procedures, rules and people in an attempt to base decisions on verifiable facts and persuasive arguments. Nickols (2010) promises that with analytic skills, a change agent though may be challenged by those who must accept and embrace change, may not be suppressed or ignored of his analysis. But the author guarantees that, because it cannot be successfully contested, it can, in most cases, carry the day. The most important two skills that change agents must learn and have are: "(1) work flow operations or systems analysis and (2) and financial analysis" (Nickols, 2010:8).

\subsection{People's skills}

The change agent, in the process of change does not deal with machine people with machine minds and machine hearts; instead they are dealing with people who have feelings, attitudes, perceptions and generally deferent behaviours and such people may react to change differently. Being a leader of change, one has to focus more on human aspects of change as individuals are the main actors in sphere of intellectual capital (Sidra et al, 2006:114). These individuals have certain attitudes that need to be understood. Chang $(1994$, p. 90) submits the importance of realising that "attitudes are both cognitive and highly emotional - our minds form the attitudes, and we often react to them on a gut level". Leaders 
ought to recognise people's needs, aims and objectives and find out how they can, in a changing dynamic and complex circumstance, fit or align their inclinations with those of the organisation.

Motivating people to partake in change may also mean showing people that change is something constant and that they are in charge of such change. This would show employees that it is not some autocratic manager or leader who wants change; but that all organisational members inherently want change. Carnall (1999) laments, however, that the opposite normally happens. People often get authoritarian management, avoidance of key issues, insufficient management, no clear milestones and no feedback. However it takes a persons' person, a person rooted in membership and a person who initiates change on the ground with the ordinary workers in the lowest of hierarchy of the organisation. Leaders who initiate change at the top logically have to have the best skills and expertise in influencing people about change in the organisation. It, indeed, takes a particular personality to initiate and lead change with the people and on behalf of the organisation.

Nickols (2010) frames the idea of people's skill within the context of communication or interpersonal skills. According to this author, to be effective one must be able to listen and listen actively, to restate, to reflect, to clarify without interrogating, to draw out the speaker, to lead of direct the discussion, to plant ideas and to develop them (Nickols, 2010:8). However it is vital to look into other aspects relating to people, attitudes. Attitudes in a work environment reflect people's feelings. An attitude is the way one thinks feels and acts toward some aspect of the environment (Govender, Moodley, and Parumasur, 2005). Thus, when change occurs, leaders are required to take these complex issues of different personalities into account. For De Bruyn and Kruger (2001) suggest that communication is an important tool in the hands of leaders for ensuring and enhancing change and can be utilised to build dedication and devotion to change programmes. Different authors have recommended that management should present proposed changes in a "face-to-face open forum and that clear, consistent and accurate information with all stakeholders" is important (Fullen, 2001:32). It follows logically that people, because change will affect them directly or indirectly, must be constantly communicated with in order to increase a sense of ownership of such change.

Leaders who master the element of communication, and who constantly exploit various means of ensuring that feedback is given to workers on every progress, if any or lack thereof, and reasons for delays, are well on their way to addressing one of the major concerns of the implementers. It has furthermore been recognised that one of the major failings of the South African HE sector, delaying its effective transformation, is a shortage of skilled leadership, problematic governance and a lack of adequate management capacity (Higher Education Leadership and Management Programme, 2004).

\section{Conclusion}

Restructuring in a form of change of roles, responsibilities through the change of policies, procedures, rules already implies that a psychological contract is being tempered with. Such a contract is a set of intangible, non-verbal and unwritten reciprocal expectations, perceptions and beliefs that characterise the interaction between the employer and employee (Sparrow and Cooper, 1998). Because these are not written expectations but are implied obligations on both parties, during restructuring, leadership and management is faced with a challenge of satisfying these expectations during change. De Vries and Balazs (1997) pointed out that when an organisation enters into a contract with the employee, it enters in an unconscious choice of satisfying psychological and employment needs in exchange for the meeting of organisational goals.

An organisation is constantly adapting and can never be static in a changing environment. Consequently psychological contracts can be broken during such times of restructuring (Rousseau and Parks, 1993), and obviously this affects the workers in a special way and as such needs proper handling. However Herriot (1992) seems to suggest that employees and employers can renegotiate the contract anytime. This is not as easy as Herriot makes it to be. There are far great implications if workers become uncertain about how the new structure in place is capable of retaining the status quo benefits, or if the possible loss of current status is not adequately dealt with in terms of helping the employees cope and adapt with a view of long term benefits.

\section{References}

Ajay, O. (2002). Leading change. USA: Capstone Publishing.

Barker, R.A. (1997). How can we train leaders if we do not know what leadership is? Human Relations, 50(4): 343-362.

Barnard \& Stoll. (2010). Organisational Change Management: A rapid literature review. Retrieved: May, 25, 2014, from http://www.cubec.org.ukl 
Baron, J.N., Hannan, M.T. and Burton M.D. (2001). Labour pains: Change in organisational models and employee turnover in young, high-tech firms. American Journal of Sociology, 106(4): 960-1012.

Barrett, D. (2008). Leadership communication for today's corporate leaders. Rice University: IABC, Luncheon

Bateman, T.S. \& Snell, S.A. (2002). Management: Competing in the New Era. McGraw-Hill Irwin: Boston

Benveniste, G. (1989). Mastering the politics of planning. San Francisco: Jossey-Bass.

Bossidy, L., \& Charan, R. (2002). Execution: The discipline of getting things done. New York: Crown.

BuaNews (2003). Higher education mergers named. Retrieved May 24, 2014, from http://www.buanews.gov.za/news/12/1204041235 1001.

Burnes, B. (2004). Managing Change: A Strategic Approach to Organisational Dynamics. $4^{\text {th }}$ Ed. Harlow: Prentice Hall.

Carnall, C. (1999). Managing change in organizations. London: Prentice Hall.

Chang, R.Y. (1994). Mastering change management: A practical guide to turning obstacles into opportunities. US: Richard Change Associates Inc.

Chen, S.S. \& Chang, L.K.C. (2001). Exploring technical and vocational education (TVE) leader's character and their beliefs and attitudes towards TVE. Journal of Technology, 16(4):605-11.

Chen, S.S. (2003). The philosophy of existence and cognition, Journal of Dahan Institute of Technology, 18:35-52.

Chen, S.S. (2006). Leadership styles and organization structural configurations. The Journal of Human Resource and Adult Learning, February, $39-45$.

CHET (2008). Report compiled for the Task Team by Nico Cloete. The report reflects the views of the author, and not the Task Team. Ministerial Task Team University of the North West (Mafikeng Campus).

Coon, D. (1998). Introduction to Psychology. Brooks/Cole Publishing Company: Pacific Grove, CA.

Daft, R.L. \& Marcic, D. (2004). Understanding Management. South-Western, Mason: Ohio.

Daft, R.L. (1998). Organization Theory and Design, South-Western College, Publishing, Cincinnati, Ohio

Dahl, M.S. (2010). Organisational change and employee stress. Druid, Aalborg University: Denmark.

De Bruyn, H.E.C. \& Kruger, S. (2001). 3rd ed. Strategic Management: A South African perspective. Johannesburg: Entrepro Publishers

De Vries, M. \& Balazs, K. (1997). The downside of downsizing. Human Relations, 50(1):11-50.

Eisenbac, R., Watson, K. \& Pillia, R. (1999). Transformational leadership in the context of organisational change. Journal of Organisational Change Management, 12(2): 80-88.

Fullan, M. (2001). Leading in a culture of change. San Francisco: Jossey-Bass.

Gilley, A. (2005). The manager as change leader. Westport, CT: Praeger

Govender, P., Moodley, S. \& Parumasur, S.B. (2005). The management of change at selected Higher Education Institutions: An exploration of the critical ingredients for effective change management. South African Journal of Industrial Psychology, 31(1):7686.

Groenewald, A. \& Ashfield G. (2008) when leaders are also explorers. The Star Workplace, 7 May, pp. 56.

Harman, G. \& Harman, K. (2003). Institutional mergers in higher education: Lessons from International Experience. Tertiary Education and Management, 9 (1): 29-44.

Harman, K. \& Meek L.V. 2002. Introduction - Merger revisited: international perspectives on mergers in higher education. Higher Education, 44(1): 1-4

Herriot, P (1992). The Career Management Challenge: Balancing Individual and Organisational Needs. Sage: London.

Higher Education Leadership and Management Programme. (2004). retrieved June, 30, 2014 from: http://www.sauvca.org.za /keyprojects/.

Higher Education Quality Committee, (2011). Audit report on Walter Sisulu University. (Higher Education Quality Committee Report) (cmnd. 33) Council on Higher Education.

Hughes, M. (2010).The leadership of change. In M. Hughes (Ed.). Managing change: A critical perspective. London: CIPD.

Jansen, J. (2003). Mergers in South African higher education: Theorising change in transitional contexts. Retrieved May 12, 2014, from http://repository.up.ac.za/xmlui/bitstream/handle/2263/118/Jansen\%20(2003)a.pdf?=3

Kinicki, A. \& Williams, B.K. (2003). Management. McGraw-Hill: Boston.

Kotter, J. (1995). Leading change: Why transformation efforts fail. Harvard Business Review, March - April, 59 - 67.

Kotter, J.P. (1990). A force for change: How leadership differs from management. New York: The Free Press.

Kotter, J.P. (1996). Leading change. Boston: Harvard Business School Press.

Kotter, J.P. (1998). What leaders really do? USA: Harvard business school press.

Kritsonis, A. (2005). Comparison of change theories. International journal of scholarly academic intellectual diversity, 8 (1):1-7.

Kruger, S. (2003). Change dynamics: Business Management. Unpublished Lecture notes.

Lalla, V. (2009). The impact of the merger on the employees of Tshwane University of Technology. Unpublished Masters Dissertation, Faculty of Humanities, University of Pretoria. South Africa.

Leanna R.C. \& Barry, B. (2000). Stability and change as simultaneous experiences in organisational life. The Academy of Management Review, 25(4): 753-759.

Lewin, K. (1951). Field Theory in Social Science: Selected Theoretical papers by Kurt

Mabey, C. (2007). Fundamentals of senior management: Managing projects and change. $3^{\text {rd }}$ ed. Hobbs the printer Ltd: Hampshire. United Kingdom. 
Mantashe, L.X. (2013). Stakeholder perceptions on the impact of the Walter Sisulu University (WSU) Turnaround Strategy (TS), with special reference to the Divisional Management Model (DMM). Unpublished Honours mini dissertation, Walter Sisulu University, Butterworth. South Africa.

Mapasela, M. \& Hay, H.R. (2005). Through the magnifying glass: A descriptive theoretical analysis of possible impact of the South African higher education policies on academic staff and their job satisfaction. Higher Education 50: 111-128.

Nadler D. and Nadler, T.M. (1998). Champions of change: how CEOs of companies are mastering the skills of radical change. San Francisco: Josse-Bass Publishers

Ncayiyana, D.J. (2011). Report of the independent assessor into the affairs of the Walter Sisulu University, appointed by the minister of Higher Education and Training. (Report of the independent assessor) (Cmnd 34641). Department of Higher Education and Training.

Nickols, J. (2010). The Invisible Cost of Organisational Restructuring. A Theory of Disengagement, University of Wales, College of Medicine and Centre for Health Leadership (Wales).

Paton and McClarlma 2001 Paton, R.A. \& McCalman, J. (2001). Change management: A guide to effective implementation. London: SAGE.

Pèli, G.L., Pólos, L., \& Hannan, M.T. (2000). Back to inertia: Theoretical implication of alternative styles of logical formalization. Sociological Theory, 18 (2):195-215.

Plotnik, R. (1996). Introduction to Psychology. Brooks/Cole Publishing Company, Pacific Grove, CA.

Rousseau, D.M. \& Parks, J.M. (1993). The contracts of individuals and organisations. Research in organisational behaviour, 15:1 - 41.

Rue, L.W. and Byars, L.L. (2003). Management. McGraw-Hill, Boston.

Ruth, T. (1996). The attributes of leadership. Leadership \& Organization Development Journal, 17(1):27-31

Schraeder, M. \& Self, D.R. (2003). Enhancing the success of mergers and acquisitions: An organisational culture perspective. Management Decision 41(5): 511-522. Retrieved: May, 30, 2014, from http://dx.doi.org/10.1108/00251740310479359

Schuller, T. (1996). The changing university. Buckingham: SRHE and Open University Press.

Schultz, C.M. (2009). Building a human resource strategy for a merging higher education institution in South Africa. South African Journal of Labour Relations, 33(2): 11-18.

Seijts, G.H. \& O'Farrell. (2003). Engage the heart: Appealing to the emotions facilitates change. Ivey Business Journal, January/February 2003, pp. 1-5.

Senge, M, P. (1990). The Leader's New Work: Building Learning Organizations. Sloan Management Review, 7-23.

Shneiderman, B. and Plaisant, C. (2005). Designing the user interface - strategies for effective human-computer interaction. $4^{\text {th }}$ Edition. Reading, MA: Addison-Wesley.

Sidra, A., Zuhair, M.F., Noman, S. \& Sajid, A. (2006). Role of Leadership in Change Management Process. Abasyn Journal of Social Sciences, 5(2):111-124.

Sidumba, L. (2011). Don't close under-fire Medusa - report. News24. Retrieved: July, 24, 2011, from http://www.news24.com/ SouthAfrica/Politics/The-university-nobody-wants-to-touch-20110723-2

Skodvin, O.J. (1999). Mergers in higher education - success or failure? Tertiary Education and Management, 5:65-80

Sparrow, P. \& Cooper, C. L. (1998). New organisational forms: The strategic relevance of Future Psychological contract Scenarios. Canadian Journal of Administrative Sciences, 15(4):356.

Stumpf, R.H. (2008). Evaluation of North-West University's management model. (Report compiled by Dr RH Stumpf, consultant at the request of NWU). September 2008. Unpublished.

Van Rooyen, G. (2000). Strategizing and managing in a crisis: Lessons from the Public Sector. In N. Cloete, I. Bunting \& T. Kulati. (Eds.). Leadership and institutional change in higher education. Pretoria: Centre for Higher Education Transformation.

Van Straaten Theron, A. \& Dodd, N.M. (2011). Organisational commitment in a post-merger situation. South African Journal of Economic and Management Sciences 14(3): 333- 345.

Viljoen, J.P. \& Rothman, S., (2002). Transformation in a tertiary education institution: a case study. Management Dynamics 11(2): 2-10.

Walter Sisulu University, (2012). Turnaround strategy. Institutional strategies, goals and objectives. 1st issue. First Draft. Walter Sisulu University.

Williams, A., Woodward, S., \& Dobson, P. (2002). Managing change successfully. Using theory and practice to implement change. Australia: Thomson.

Wyngaard, A. \& Kapp, C. (2004). Rethinking and reimagining mergers in further and higher education: A human perspective. South African Journal of Higher Education 18(1): 185-201. Retrieved: May, 28, 2014, from http://dx.doi.org/10.4314/ sajhe.v18i1.25437.

Zalenick, A. (1997). Managers and leaders: Are they different? Harvard Business Review, 55(5): 67-78 